\title{
In vitro fermentation, digestibility and methane production of tropical perennial grass species
}

\author{
Belete Shenkute Gemeda ${ }^{\mathrm{A}, \mathrm{B}}$ and Abubeker Hassen ${ }^{\mathrm{A}, \mathrm{B}}$ \\ ${ }^{A}$ Department of Animal and Wildlife Sciences, University of Pretoria, Pretoria 0002, South Africa. ${ }^{\mathrm{B} C o r r e s p o n d i n g ~ a u t h o r s . ~}$ \\ Emails: beletegemeda@gmail.com; Abubeker.hassen@up.ac.za
}

\begin{abstract}
This study characterised 16 tropical perennial grass species in terms of in vitro methane output and related their digestibility and rumen fermentation with methane output. The grass samples were collected, dried in a forced oven, and ground and analysed for nutrient composition. In vitro gas production and organic matter digestibility (IVOMD) were determined using rumen fluid collected, strained and anaerobically prepared. A semi-automated system was used to measure gas production through in vitro incubation at $39^{\circ} \mathrm{C}$. Anthephora argentea and Stipagrostis ciliate produced the highest concentration of methane in terms of $\mathrm{g} \mathrm{kg}^{-1}$ digestible dry matter (DDM) and $\mathrm{g} \mathrm{kg}^{-1}$ digestible organic matter (IVOMD). Cenchrus ciliaris, Setaria verticillata and Panicum coloratum produced the lowest $(P<0.05)$ methane when expressed in terms of $\mathrm{g} \mathrm{kg}^{-1} \mathrm{DDM}$ and $\mathrm{g} \mathrm{kg}^{-1}$ IVOMD. Ash, ether extract, non-fibrous carbohydrate, neutral and acid detergent insoluble nitrogen, and crude protein were negatively correlated with methane production. Methane production positively correlated with neutral and acid detergent fibre, cellulose and hemicellulose. It is important to focus on screening and selecting perennial grass with higher nitrogen content and low methane production to mitigate methane production under tropical conditions.
\end{abstract}

Additional keywords: digestibility, fermentation, methane, perennial grass, tropical.

\section{Introduction}

Enteric methane $\left(\mathrm{CH}_{4}\right)$ production in ruminants decreases their energy utilisation efficiency and contributes to the global greenhouse-gas effect. Methane is produced under anaerobic conditions by rumen microorganisms, called methanogenic archaea, that gain energy by reducing $\mathrm{CO}_{2}$ with $\mathrm{H}_{2}$ to form $\mathrm{CH}_{4}$ (Leng 2008). Ruminal microbes convert major portions of carbohydrate and protein in feed to volatile fatty acids, microbial protein, methane and $\mathrm{CO}_{2}$. Enteric methane production depends primarily on quantity and quality of the diet (Van Soest 1994; Beauchemin et al. 2009), the nature of fermented carbohydrates (Santoso et al. 2003), the concentrations of neutral (NDF) and acid (ADF) detergent fibres (Hindrichsen et al. 2003), the ratio of acetate to propionate in fermented feeds (McAllister et al. 1996), and type and maturity stages of forage consumed by the animal (Arthington and Brown 2005).

Mitigation of methane production from ruminants by altering the diet is an effective way to decrease enteric methane production (Singh et al. 2012). An increased proportion of concentrate in ruminant rations is generally associated with a reduction in methane emission per unit of feed intake and per unit of animal product (Johnson and Johnson 1995; Lovett et al. 2003). However, in many tropical and subtropical livestock production systems, ruminants receive small quantities of concentrates, if at all, because of unavailability and cost. Therefore, under such systems, it is important to focus on tropical grassland forages and to design effective feed-based mitigation strategies. Previous research has suggested that increased forage quality will reduce methane emissions per unit of weight gain (Mc Geough et al. 2010) or per unit of animal product (Moss 2000), due to improvement in animal productivity.

Characterisation of tropical grasses and relating those attributes to potential methane production is important for selection and improvement through breeding. Methane production is mainly related to the extent of organic matter digestion and the profile of volatile fatty acids produced and fermented (McDonald et al. 2011). Thus, methane output from a wide range of grass species can be studied using in vitro gasproduction techniques; this method is inexpensive and widely used (Tavendale et al. 2005). For tropical grass species in Africa, little information is documented on their potential methane outputs and the correlation with their nutrient constituents. Therefore, this study was undertaken with the aim of providing information on grass species commonly found in the Kalahari Desert of Southern Africa. The specific objectives were: (i) to characterise the grass species in terms of chemical composition and related attributes; (ii) to compare in vitro gas production and methane output of various tropical grass species; and (iii) to relate methane production of grass species to their chemical composition, digestibility and in vitro gas production attributes. 


\section{Materials and methods}

\section{Study area description}

The study was carried out in North West Province of South Africa, in the Thorny Kalahari Dune Bushveld, which covers 2000 ha with an altitude of $\sim 900-1100 \mathrm{~m}$ a.s.l. It is a fenced area with rotation-grazed paddocks. The carrying capacity is 13.2 tropical livestock units (TLU) and the land is used for livestock farming (96\%), including beef cattle, sheep and goats. Soils are red, excessively drained sandy soils with high base status; dunes are present and there are elevated concentrations of copper, which is bound in the soil in the form of the secondary copper hydroxyl mineral atacamite $\left(\mathrm{Cu}_{2}(\mathrm{OH})_{3} \mathrm{Cl}\right)$ (Le Roux 2013). The area has highly erratic rainfall that ranges from 150 to $350 \mathrm{~mm}$ per year; however, it barely exceeded $150 \mathrm{~mm}$ during the study period or the previous 2 years. The wettest months are usually January-April and the temperature extremes range from winter lows reaching $-10.3^{\circ} \mathrm{C}$ to summer highs of up to $45.4^{\circ} \mathrm{C}$ (Rooyen 2001).

The study area has sparsely scattered trees, mainly camel thorn (Acacia erioloba), false umbrella thorn (Acacia luederitzii) and shepherd's tree (Boscia lehmanniana). The dominant herbaceous plants are perennial rather than annual grasses. Some of the dominant perennial grasses include Eragrostis spp., Schmidtia spp. and Stipagrostis spp.

\section{Grass sampling and chemical composition analysis}

The study area was categorised as lightly grazed and heavily grazed according to grazing histories and condition of the rangeland. In each grazing site, eight transects, each $7.5 \mathrm{~m}$ long, were set up in the canopied and uncanopied sub-habitat. Data on floristic composition, total plant cover and individual species cover were collected using the quadrat point method (Daget and Poissonet 1971). To obtain dry matter (DM) of aboveground parts of vegetation, we used the formula of Le Houe'rou (1987).

From each transect, four randomly selected sub-sites were taken. The herbaceous vegetation was cut at ground level using a $50 \mathrm{~cm}$ by $50 \mathrm{~cm}$ quadrat and immediately identified and categorised into perennial grasses, annuals, legumes and sedges. Perennial grasses were separated into species and put in paper bags for further study. Sampling was done when most pasture plants were fully grown and were flowering (important for identification). The perennial grass species common to both study sites were used for determination of nutritive value, and in vitro fermentation and methane production.

The grasses were kept under a shaded area until transported to the Nutrition Laboratory of University of Pretoria, where they were oven-dried $\left(55^{\circ} \mathrm{C}\right.$ for $\left.48 \mathrm{~h}\right)$. For all in vitro studies and chemical composition analyses, the samples were ground to pass through a 1-mm sieve in a Willey mill (Arthur H. Thomas, Philadelphia, PA, USA). The samples were analysed for organic matter (OM) by ashing in a muffle furnace at $550^{\circ} \mathrm{C}$ (AOAC 2002). Crude protein (CP) was measured according to the combustion method (AOAC 2002) for nitrogen (N) on a LECO FP-428 Nitrogen and Protein analyzer (LECO Corporation, St. Joseph, MI, USA), and ether extract (fat) was done according to AOAC (2002) procedures. The NDF and ADF contents were determined using an ANKOM200/220 Fibre Analyzer
(ANKOM Technology, Fairport, NY, USA) based on the methods described by Van Soest et al. (1991). Sodium sulfite and heat-stable amylase were used in the analysis of NDF. Lignin (ADL) was determined by solubilisation of cellulose with sulfuric acid in the ADF residue (Van Soest et al. 1991). The N contents of NDF and ADF (i.e. neutral (NDIN) and acid (ADIN) detergent insoluble $\mathrm{N}$ ) were determined by the $\mathrm{CP}$ method referenced above and expressed exclusive of residual ash. The non-fibre carbohydrate (NFC) content of feeds was calculated by subtraction of CP, NDF, fat and ash from total DM (Sniffen et al. 1992). Hemicellulose was estimated from the difference between NDF and ADF, while cellulose was estimated as the difference between ADF and ADL.

\section{In vitro gas production measurement \\ Collection of rumen fluid from donor sheep}

Rumen fluid was collected before the morning feeding from two ruminally cannulated Merino wethers fed on ad libitum lucerne (Medicago sativa) hay. Approximately $500 \mathrm{~mL}$ rumen fluid was collected from each donor animal, mixed, strained through four layers of cheesecloth, and transferred to a preheated thermos flask. In the laboratory, the flask contents were emptied into an industrial blender and simultaneously purged with $\mathrm{CO}_{2}$ to maintain anaerobic conditions (Grant and Mertens 1992). After blending, the rumen fluid was transferred in a large glass beaker that was kept inside a $39^{\circ} \mathrm{C}$ water bath purged with $\mathrm{CO}_{2}$ and continuously stirred as recommended by Goering and Van Soest (1970). Thereafter, $15 \mathrm{~mL}$ rumen fluid was added to $25 \mathrm{~mL}$ buffer solution in the respective incubation bottles.

\section{Buffer media preparation, sample incubation and gas measurement}

The buffer solution, macro-mineral solution and micromineral solution were prepared in large quantities and utilised as required following the procedure described by Goering and Van Soest (1970). The micro-mineral solution was prepared with a slight modification whereby $\mathrm{MgSO}_{4} .7 \mathrm{H}_{2} \mathrm{O}$ was replaced with $\mathrm{MgCl}_{2} \cdot 6 \mathrm{H}_{2} \mathrm{O}$ to reduce the amount of $\mathrm{SO}_{4}$ in the media, as suggested by Mould et al. ( 2005). It was stored in a dark glass bottle to maintain the quality of the solution. In the morning, before the start of the experiment, appropriate amounts of distilled water, rumen buffer solution, and macro- and micromineral solutions were mixed with tryptose and prepared $0.1 \%$ (wt/vol.) resazurin. Appropriate amounts of L-cysteine hydrochloride were weighed and added directly to the rest of the solution once all of the chemicals were dissolved. As soon as Lcysteine hydrochloride was added, the buffer solution was placed in a $39^{\circ} \mathrm{C}$ water bath and bubbled with $\mathrm{CO}_{2}$. The serum bottles were then sealed with a rubber stopper and left at $39^{\circ} \mathrm{C}$ until the buffer solution was clear, which indicated that the solution was sufficiently reduced.

A semi-automated gas production system was used to measure gas production through in vitro incubation at $39^{\circ} \mathrm{C}$, according to Theodorou et al. (1994). The system consists of a digital data tracker (Tracker 220 series indicators; Omega Engineering Inc., Laval, QC, Canada) connected to a pressure transducer (PX4200-015GI; Omega Engineering Inc.) with a needle on the tip. Approximately $400 \mathrm{mg}$ of each grass-feed sample was weighed into 120 -mL serum bottles, then $40 \mathrm{~mL}$ 
rumen fluid + medium was added under a stream of $\mathrm{CO}_{2}$ to each of the serum bottles closed with rubber stoppers and crimp seal caps. A needle was inserted through the rubber stopper of each serum bottle for $\sim 5 \mathrm{~s}$ to release small amounts of gas that might have built up since the start of incubation. All serum bottles were placed in the incubator and the rotary shaker was turned on at $120 \mathrm{rpm}$. Gas pressure was taken at 2, 4, 8, 12, 24, 32, 48, 54 and $72 \mathrm{~h}$. To quantify the gas production derived from the culture medium and the rumen inoculums, two blanks were included in every analysis. Two replicates were used in each run and four different runs were executed for every grass sample included in the study. The pressure and gas volume were recorded at different times and were added to the values of the previous readings. Thus, the cumulative pressure and gas volume of the fermentation were obtained. Fermentation was terminated after $72 \mathrm{~h}$ by removing serum bottles from the incubator and placing them on ice. Supernatants were immediately pipetted and stored at 208C until analysed for - ammonia-N (McDonald et al. 1960) and volatile fatty acids . (Ottenstein and Bartley 1971)

\section{In vitro digestible organic matter determination}

The in vitro digestible organic matter (IVOMD) content was determined according to the method of Tilley and Terry (1963), as modified by Engels and Van der Merwe (1967). The method involved two digestion phases. During the first digestion phase, feed samples $(200 \mathrm{mg})$ were incubated in triplicate under anaerobic conditions with rumen liquor for $48 \mathrm{~h}$ at $39^{\circ} \mathrm{C}$, with the inclusion of blanks and standards in every batch of incubation. This was followed by an acid pepsin digestion phase for $48 \mathrm{~h}$ at $39^{\circ} \mathrm{C}$, under anaerobic conditions. Following the incubation for $96 \mathrm{~h}$, the residual plant materials were collected and oven-dried at $105^{\circ} \mathrm{C}$ for $12 \mathrm{~h}$. Ash contents were determined by combustion at $550^{\circ} \mathrm{C}$ for $2 \mathrm{~h}$ (Engels and Van der Merwe 1967).

Methane production measurements

Methane production was measured from the duplicate bottles incubated with each grass sample at 2, 12, 24 and $48 \mathrm{~h}$. The methane concentration was determined by gas chromatography (8610C Gas Chromatograph (GC) BTU Gas Analyzer GC System; SRI Instruments GmbH, Bad Honnef, Germany). The GC was equipped with a solenoid column packed with silica gel and a flame ionisation detector. Gas production from each bottle was recorded and gas samples were immediately taken using a Hamilton syringe. The sampled gas was injected manually (pull and push method of sample injection) into the $\mathrm{GC}$, which was already calibrated with standard methane and $\mathrm{CO}_{2}$. Two blanks were included for correction of methane produced from the inoculum in each run, and two runs were executed for each samples. The measured methane concentration was related to the respective total gas measurement in order to estimate its concentration (Tavendale et al. 2005), and subsequently converted to energy and mass values using $39.54 \mathrm{~kJ} \mathrm{~L}^{-1} \mathrm{CH}_{4}$ and $0.716 \mathrm{mg} \mathrm{mL}^{-1} \mathrm{CH}_{4}$ factors, respectively (Santoso et al. 2007).

\section{Calculations and statistical analyses}

Non-fibrous carbohydrate was calculated as:

$$
\mathrm{NFC}=100-(\mathrm{CP}+\text { fat }+\mathrm{ash}+(\mathrm{NDF}-\mathrm{NDIN}))
$$

Metabolisable energy (ME, MJ kg-1 DM) was estimated according to Menke and Steingass (1988) as:

$$
\begin{aligned}
\mathrm{ME}\left(\mathrm{MJ} \mathrm{kg}^{-1} \mathrm{DM}\right)= & 2.20+0.136 \mathrm{IVGP} 24(\mathrm{~mL} \text { per } 0.5 \mathrm{~g} \mathrm{DM}) \\
& +0.057 \mathrm{CP}(\% \mathrm{DM})
\end{aligned}
$$

where IVGP24 is in vitro gas production over $24 \mathrm{~h}$. Methane production was calculated as:

$\mathrm{CH}_{4}$ produced $\left(\mathrm{g} \mathrm{g}^{-1}\right.$ digested DM $)=(($ gas production $24 \mathrm{~h}$

$\times\left(\left[\mathrm{CH}_{4} 24 \mathrm{~h}\right]\right)-$ gas produced blank $24 \mathrm{~h}$

$\times\left[\mathrm{CH}_{4}\right.$ blank $\left.\left.\left.24 \mathrm{~h}\right]\right)\right) / \mathrm{g}$ digested DM

according to Chaves et al. (2006).

The rate and extent of gas production was determined for each grass species by fitting gas production data to the non-linear equation (Ørskov and Mcdonald 1979):

$$
y=b\left(1-\mathrm{e}^{-c t}\right)
$$

where $y$ is gas production at time $t ; b$ is the slowly fermentable fraction $\left(\mathrm{g} \mathrm{kg}^{-1} \mathrm{DM}\right)$; and $c$ is the rate $\left(\% \mathrm{~h}^{-1}\right)$ of fermentation of fraction $b$.

The experimental design used in the study was a completely randomised design. The data were statistically analysed using the GLM option of SAS (2002) and differences among the means were determined using Tukey's test. The in vitro incubation times were used to fit non-linear regression models using the NLIN procedure (SAS 2002).

\section{Result}

\section{Plant cover, density and dry matter yield}

At the lightly grazed site, there was a significant difference $(P<0.05)$ between the canopied and uncanopied areas for total plant cover and DM yield. However, there was no significant $(P>0.05)$ difference between the two areas at the heavily grazed site in terms of the two parameters. Total plant cover and the DM yield values tended to be higher under tree canopy (Table 1).

The mean perennial species cover ( $\%$ of DM) at the study sites is shown in Table 2 (only species presenting a cover $>0.5 \%$ are indicated). At the lightly grazed site, the perennial grass species cover showed significant differences $(P<0.05)$ for some Aristida vestita, Schmidtia pappophoroides, Stipagrostis ciliate and Stipagrostis obtuse. The highest cover of these species was recorded under the tree canopy and it varied from $0.99 \%$ to $10.3 \%$ in the canopied sub-habitat. The most abundant species at both grazing sites were Schmidtia pappophoroides, Stipagrostis ciliate, Stipagrostis obtuse and Stipagrostis uniplumis.

\section{Chemical composition}

Table 3 summarises the chemical compositions of grass species used in the study. Significant $(P<0.05)$ variation in terms of chemical composition was recorded for different grass species. The highest ash concentration was recorded for Setaria verticillata (147 $\left.\mathrm{g} \mathrm{kg}^{-1} \mathrm{DM}\right)$ and the lowest value for Panicum coloratum $\left(20 \mathrm{~g} \mathrm{~kg}^{-1} \mathrm{DM}\right)$. CP content in the grass species ranged between 20 and $126 \mathrm{~g} \mathrm{~kg}^{-1} \mathrm{DM}$. The highest CP content was 
Table 1. Mean total plant cover, dry matter and density of perennial species occurring under shrubs and tree canopies and in open areas in (lightly grazed site) and outside (heavily grazed site) the study area

${ }^{*} P<0.05 ;$ n.s., not significant

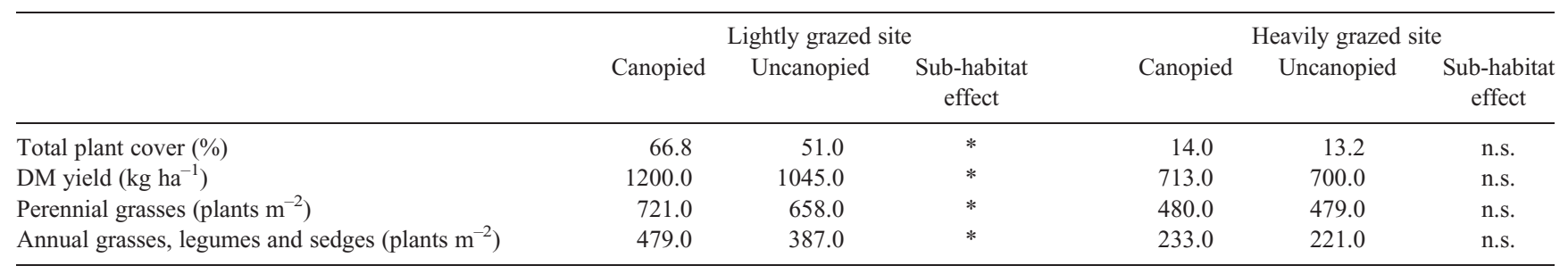

Table 2. Mean perennial grass species cover (\% of dry matter) occurring under tree canopies (Can.) and in open areas (Uncan.) in (lightly grazed site) and outside (heavily grazed site) the study area

$* P<0.05 ;$ n.s., not significant

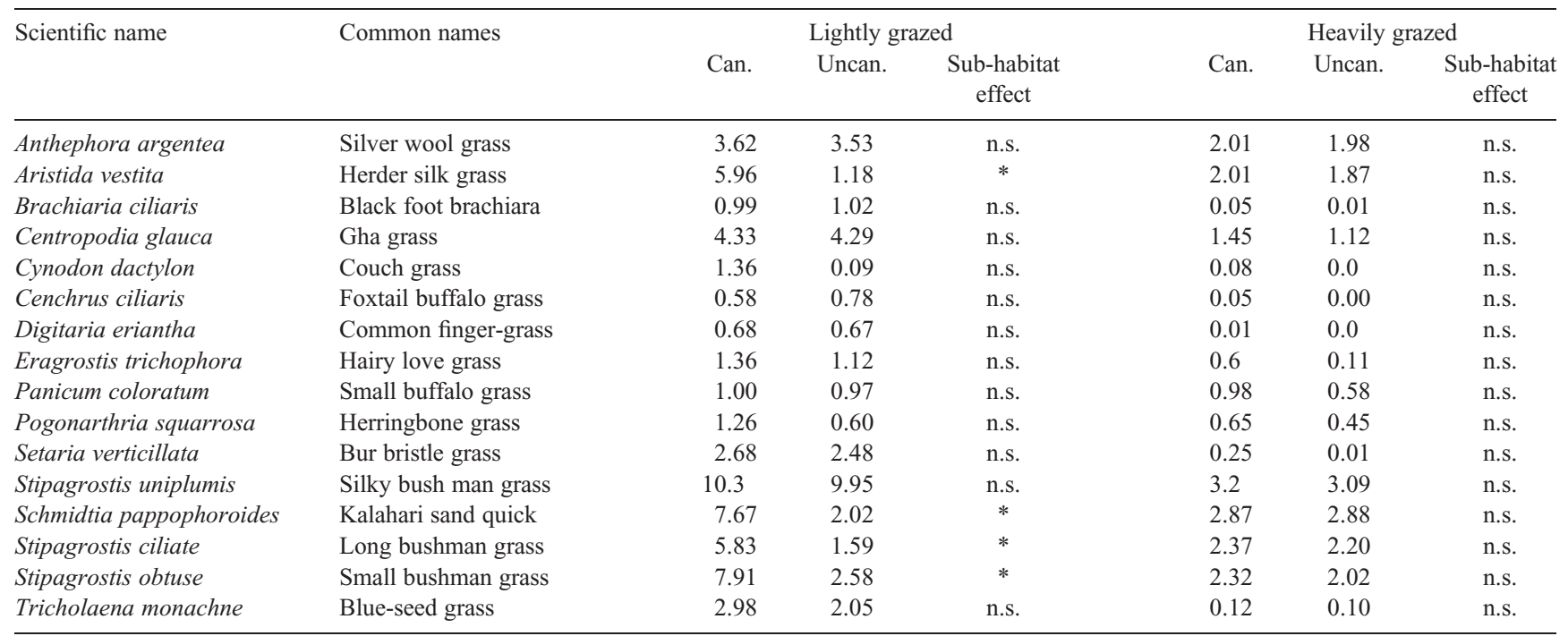

Table 3. Mean of chemical composition $\left(\mathrm{g} \mathrm{kg}^{-1} \mathrm{DM}\right)$ of tropical grass species used the study

OM, Organic matter; CP, crude protein; EE, ether extract; NDF and ADF, neutral and acid detergent fibre; ADL, acid detergent lignin; ADIN and NDIN, acid and neutral detergent insoluble nitrogen. Within a column, means followed by the same letter are not significantly different at $P=0.05$

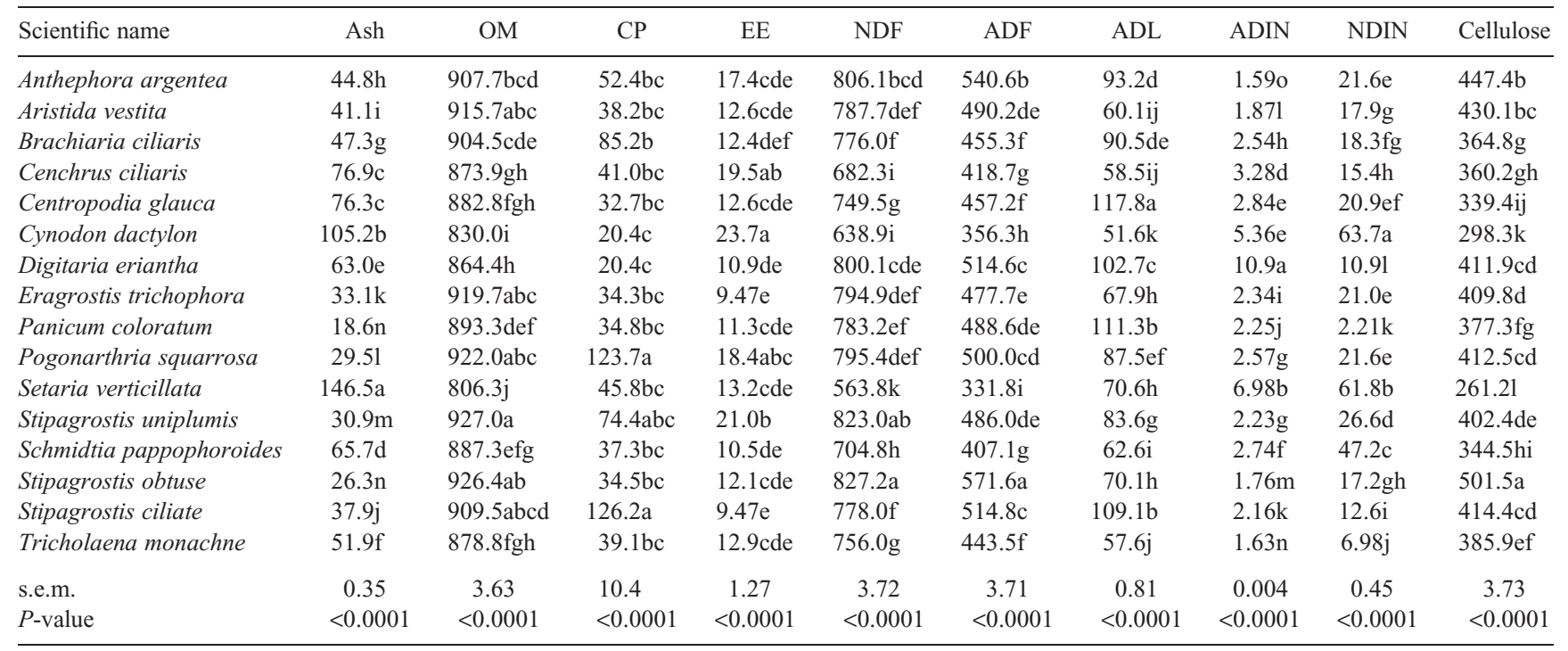


recorded for Pogonarthria squarrosa (124 $\left.\mathrm{g} \mathrm{kg}^{-1} \mathrm{DM}\right)$ and Stipagrostis ciliate (126 $\left.\mathrm{g} \mathrm{kg}^{-1} \mathrm{DM}\right)$ and the lowest amount for Cynodon dactylon and Digitaria eriantha $\left(20 \mathrm{~g} \mathrm{~kg}^{-1} \mathrm{DM}\right)$. Cynodon dactylon had the highest value of NDIN $\left(64 \mathrm{~g} \mathrm{~kg}^{-1}\right.$ DM-NDF) and Panicum coloratum the lowest value $\left(2.21 \mathrm{~g} \mathrm{~kg}^{-1}\right.$ $\mathrm{DM})$. The highest value of ADIN was recorded in Digitaria eriantha $\left(11 \mathrm{~g} \mathrm{~kg}^{-1} \mathrm{DM}-\mathrm{ADN}\right)$ and the lowest value in Anthephora argentea $\left(1.59 \mathrm{~g} \mathrm{~kg}^{-1} \mathrm{DM}\right)$.

The NDF ranged from 564 to $827 \mathrm{~g} \mathrm{~kg}^{-1} \mathrm{DM}$, and ADF ranged from 332 to $572 \mathrm{~g} \mathrm{~kg}^{-1} \mathrm{DM}$. Stipagrostis obtusa had the highest values of NDF $\left(827 \mathrm{~g} \mathrm{~kg}^{-1} \mathrm{DM}\right)$ and ADF $\left(572 \mathrm{~g} \mathrm{~kg}^{-1} \mathrm{DM}\right)$, and Setaria verticillata the lowest NDF $\left(564 \mathrm{~g} \mathrm{~kg}^{-1} \mathrm{DM}\right)$ and ADF (332 $\left.\mathrm{g} \mathrm{kg}^{-1} \mathrm{DM}\right)$. Centropodia glauca had the highest ADL (118 $\left.\mathrm{g} \mathrm{kg}^{-1} \mathrm{DM}\right)$ content, whereas the lowest value was recorded for Cynodon dactylon ( $\left.52 \mathrm{~g} \mathrm{~kg}^{-1} \mathrm{DM}\right)$. Stipagrostis obtusa had the highest cellulose $\left(502 \mathrm{~g} \mathrm{~kg}^{-1} \mathrm{DM}\right)$ and Setaria verticillata the lowest (261 $\left.\mathrm{g} \mathrm{kg}^{-1} \mathrm{DM}\right)$.

In vitro gas production, organic matter digestibility and volatile fatty acid (VFA) production

The cumulative gas production pattern from the in vitro fermentation of the grass species is given in Fig. 1. The total volume and pattern of gas production varied among species; however, the observed differences were not consistent for the different incubation times except for Schmidtia pappophoroides, which consistently produced the highest volume of gas over all incubation times. The lowest gas production was measured for Panicum coloratum at 2 and $48 \mathrm{~h}$, and Pogonarthria squarrosa during 8-72 h. Gas production was, in general, lower in these two grass species compared with the others grasses studied.
The grass species showed high variability in terms of gas production parameters and constants (Table 4 ). A higher $b$-value (gas production from the slowly fermentable OM) was recorded for Schmidtia pappophoroides $(69.7 \mathrm{~mL}$ per $0.4 \mathrm{~g} \mathrm{DM})$ and the lowest $b$-value for Panicum coloratum (26.3 mL per $0.4 \mathrm{~g} \mathrm{DM}$ ). The potential gas production value was highest for Schmidtia pappophoroides $(35.3 \mathrm{~mL}$ per $0.4 \mathrm{~g} \mathrm{DM})$, and lowest for Pogonarthria squarrosa $(10.7 \mathrm{~mL}$ per $0.4 \mathrm{~g}$ DM). The rate of gas production was highest $\left(0.057 \mathrm{~mL} \mathrm{~h}^{-1}\right)$ for Eragrostis trichophora and lowest $\left(0.029 \mathrm{~mL} \mathrm{~h}^{-1}\right)$ for Pogonarthria squarrosa.

The total and individual short-chain VFAs and ammonia-N concentration are presented in (Table 5). The total and individual short-chain VFAs varied among perennial grasses. Anthephora argentea produced large amounts of total VFAs and individual fatty acids, whereas Panicum coloratum contained the lowest amounts, except isobutyric acid.

\section{Methane production and its association with IVOMD, VFA and chemical composition}

Methane production $\left(\mathrm{mL} g \mathrm{DM}^{-1}\right)$ and its percentage concentration $(\mathrm{v} / \mathrm{v})$ in the total gas differed $(P<0.05)$ among the studied grass species and incubation periods (Table 6). Methane production and its concentration (\%) from tested perennial grasses differed significantly $(P<0.05)$ at different periods of incubation. The volume of methane production was higher $(P<$ 0.05) from Stipagrostis ciliate, Anthephora argentea and Aristida vestita during the early incubation period $(2 \mathrm{~h})$, whereas Stipagrostis ciliate and Aristida vestita produced significantly $(P$ $<0.05$ ) higher volumes of methane during $12-48 \mathrm{~h}$ of

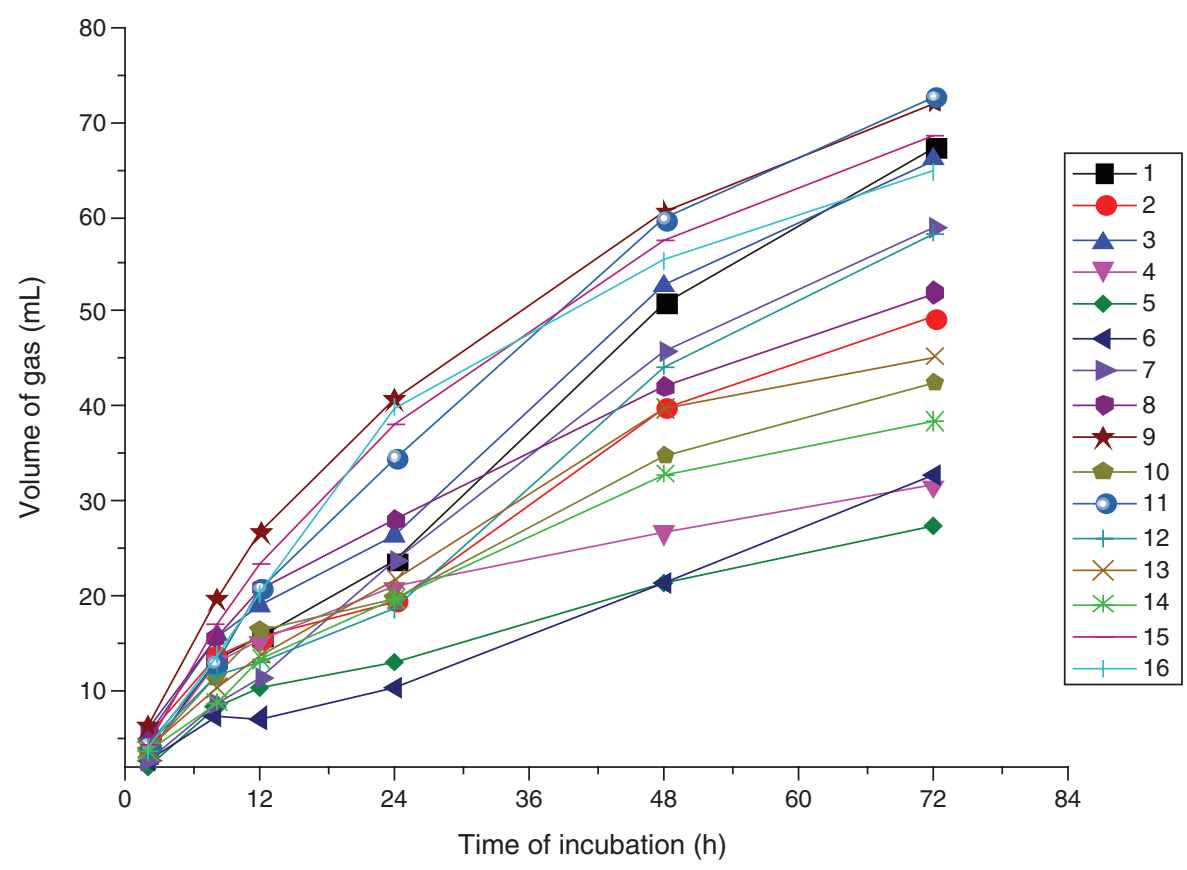

Fig. 1. Gas production (mL per $400 \mathrm{mg} \mathrm{DM}$ ) pattern of tropical perennial grasses used in the study. 1, Anthephora argentea; 2, Brachiaria ciliaris; 3, Cenchrus ciliaris; 4, Eragrostis trichophora; 5, Panicum coloratum; 6, Pogonarthria squarrosa; 7, Setaria verticillata; 8, Stipagrostis uniplumis; 9, Schmidtia pappophoroides; 10, Centropodia glauca; 11, Stipagrostis obtuse; 12, Aristida vestita; 13, Tricholaena monachne; 14, Stipagrostis ciliate; 15, Cynodon dactylon; 16, Digitaria eriantha. 
incubation. The lowest volume of methane was recorded for Stipagrostis uniplumis during the early incubation period (2 h), whereas Cenchrus ciliaris and Panicum coloratum produced the lowest volume during $12-48 \mathrm{~h}$ of incubation.

Methane production expressed in mass (methane production, $\mathrm{g} \mathrm{kg}^{-1} \mathrm{DM}$ and $\mathrm{g} \mathrm{kg}^{-1}$ IVOMD) and eructated energy (\%ME) also varied significantly $(P<0.05)$ among the studied grasses (Table 7). Cynodon dactylon and Tricholaena monachne

Table 4. Gas production parameters of tropical perennial grasses used in the study

Units for $b$ (slowly fermentable fraction) and PD (potential) are $\mathrm{mL}$ per $0.4 \mathrm{~g}$ $\mathrm{DM}$; units for $c$ (rate of fermentation of fraction $b$ ) are $\mathrm{mL} \mathrm{h}^{-1}$. With columns, means followed by the same letter are not significantly different at $P=0.05$

\begin{tabular}{lccc}
\hline Scientific name & \multicolumn{3}{c}{ Gas production parameters } \\
& $b$ & $c$ & PD \\
\hline Anthephora argentea & $49.29 \mathrm{f}$ & $0.044 \mathrm{e}$ & $23.04 \mathrm{f}$ \\
Aristida vestita & $44.13 \mathrm{i}$ & $0.046 \mathrm{~d}$ & $21.15 \mathrm{~h}$ \\
Brachiaria ciliaris & $45.64 \mathrm{~g}$ & $0.036 \mathrm{j}$ & $19.01 \mathrm{j}$ \\
Cenchrus ciliaris & $57.79 \mathrm{e}$ & $0.038 \mathrm{i}$ & $24.95 \mathrm{e}$ \\
Centropodia glauca & 39.591 & $0.040 \mathrm{~g}$ & 17.571 \\
Cynodon dactylon & $60.059 \mathrm{c}$ & $0.047 \mathrm{c}$ & $29.0 \mathrm{~b}$ \\
Digitaria eriantha & $58.08 \mathrm{~d}$ & $0.046 \mathrm{~d}$ & $27.7 \mathrm{~d}$ \\
Eragrostis trichophora & $30.31 \mathrm{n}$ & $0.057 \mathrm{a}$ & $16.12 \mathrm{~m}$ \\
Panicum coloratum & $26.25 \mathrm{p}$ & $0.038 \mathrm{i}$ & $11.25 \mathrm{o}$ \\
Pogonarthria squarrosa & $28.98 \mathrm{o}$ & $0.029 \mathrm{k}$ & $10.71 \mathrm{p}$ \\
Setaria verticillata & $44.36 \mathrm{i}$ & $0.043 \mathrm{f}$ & $20.48 \mathrm{i}$ \\
Stipagrostis uniplumis & $45.12 \mathrm{~h}$ & $0.051 \mathrm{~b}$ & $22.76 \mathrm{~g}$ \\
Schmidtia pappophoroides & $69.71 \mathrm{a}$ & $0.051 \mathrm{~b}$ & $35.30 \mathrm{a}$ \\
Stipagrostis obtuse & $64.34 \mathrm{~b}$ & $0.039 \mathrm{~h}$ & $28.11 \mathrm{c}$ \\
Stipagrostis ciliate & $36.75 \mathrm{~m}$ & $0.039 \mathrm{~h}$ & $16.01 \mathrm{n}$ \\
Tricholaena monachne & $42.6 \mathrm{k}$ & $0.039 \mathrm{~h}$ & $18.56 \mathrm{k}$ \\
s.e.m. & 0.003 & 0.001 & 0.003 \\
P-value & $<0.0001$ & $<0.0001$ & $<0.0001$ \\
\hline
\end{tabular}

contained significantly higher $\mathrm{ME}\left(12.3 \mathrm{MJ} \mathrm{kg}^{-1} \mathrm{DM}\right)$ and IVOMD (61\%), whereas Schmidtia pappophoroides (6.21 MJ $\left.\mathrm{ME} \mathrm{kg}^{-1} \mathrm{DM}\right)$ and Stipagrostis ciliata $(40.7 \%)$ contain the lowest ME and IVOMD, respectively. The studied perennial grasses showed significant variation in their ME, IVOMD and ammonia-N contents. Anthephora argentea and Stipagrostis ciliate produced the highest concentration of methane, both in terms of $\mathrm{g} \mathrm{kg}^{-1} \mathrm{DM}$ and $\mathrm{g} \mathrm{kg}^{-1} \mathrm{DOM}$. Cenchrus ciliaris, Setaria verticillata, and Panicum coloratum produced the lowest $(P<0.005)$ methane when expressed in terms of both $\mathrm{g} \mathrm{kg}^{-1}$ $\mathrm{DM}$ and $\mathrm{g} \mathrm{kg}^{-1}$ IVOMD. Methane production expressed in terms of eructated energy was higher $(P<0.05)$ from Anthephora argentea and Stipagrostis ciliate, and this ranged between $0.335 \%$ and $1.12 \%$ across the grass species.

Methane production was negatively correlated with CP ($\left.0.357^{*}\right)$, ash $(-0.602 *)$, ether extract $\left(-0.299^{*}\right)$, NFC $\left(-0.635^{*}\right)$, NDIN $\left(-0.308^{*}\right)$ and $\operatorname{ADIN}\left(-0.398^{*}\right)$ of the grass species (Table 8). A significant positive correlation was noted between methane production and NDF $\left(0.652^{*}\right)$, ADF $\left(0.703^{*}\right)$, ADL $\left(0.371^{*}\right)$, cellulose $\left(0.658^{*}\right)$ and hemicellulose $\left(0.643^{*}\right)$. There was also a positive correlation between methane production and acetate $\left(0.307^{*}\right)$, isobutyrate $\left(0.423^{*}\right)$ and butyrate $\left(0.323^{*}\right)$.

Linear regression of methane production based on the studied parameters indicated that the equations developed based on NFC, NDF and ADF values can be regarded as better predictors of methane production $\left(\mathrm{g} \mathrm{kg} \mathrm{DM}^{-1}\right)$ (Table 9).

\section{Discussion \\ Plant cover and dry matter yield}

The higher plant cover and DM yield for the canopied sub-habitat can be attributed to the high soil fertility under trees, which might result from accumulation of soil that was swept away from

Table 5. Total and individual volatile fatty acid (mM) production, acetate to propionate ratio (A : $\mathrm{P})$, and ammonia- $\mathrm{N}(\mathrm{mg}$ per $100 \mathrm{~mL})$, in supernatant after $72 \mathrm{~h}$ incubation of $400 \mathrm{mg}$ DM of the studied grasses

For $\mathrm{NH}_{3}-\mathrm{N}$, means followed by the same letter are not significantly different at $P=0.05$

\begin{tabular}{|c|c|c|c|c|c|c|c|c|}
\hline Scientific name & $\mathrm{NH}_{3}-\mathrm{N}$ & Acetic & Propionic & Isobutyric & Butyric & Valeric & $\begin{array}{l}\text { Total } \\
\text { VFA }\end{array}$ & $\mathrm{A}: \mathrm{P}$ \\
\hline Anthephora argentea & $7.97 \mathrm{~m}$ & 91.76 & 30.29 & 2.68 & 12.21 & 2.92 & 139.9 & 3.03 \\
\hline Aristida vestita & $8.71 \mathrm{k}$ & 52.35 & 22.99 & 1.81 & 6.79 & 2.04 & 85.97 & 2.42 \\
\hline Brachiaria ciliaris & $15.3 \mathrm{~d}$ & 47.97 & 19.83 & 1.73 & 6.80 & 2.02 & 78.36 & 2.60 \\
\hline Cenchrus ciliaris & 8.701 & 56.34 & 21.68 & 1.63 & 6.17 & 2.37 & 88.19 & 3.26 \\
\hline Cynodon dactylon & $10.6 \mathrm{~h}$ & 59.58 & 18.51 & 1.97 & 7.97 & 2.51 & 90.54 & 2.90 \\
\hline Centropodia glauca & $15.4 \mathrm{c}$ & 46.47 & 16.85 & 1.70 & 5.93 & 2.10 & 73.05 & 2.20 \\
\hline Digitaria eriantha & $13.6 \mathrm{e}$ & 48.55 & 18.81 & 1.47 & 5.67 & 1.74 & 76.24 & 2.86 \\
\hline Eragrostis trichophora & $11.4 \mathrm{f}$ & 48.92 & 15.00 & 1.55 & 6.14 & 2.01 & 73.62 & 2.65 \\
\hline Panicum coloratum & $19.5 \mathrm{a}$ & 36.86 & 12.73 & 1.52 & 4.97 & 1.69 & 57.77 & 3.55 \\
\hline Pogonarthria squarrosa & $5.31 \mathrm{p}$ & 51.55 & 23.41 & 1.78 & 6.76 & 1.99 & 85.49 & 2.76 \\
\hline Setaria verticillata & $9.18 \mathrm{j}$ & 54.38 & 19.04 & 1.70 & 5.70 & 2.20 & 83.03 & 2.69 \\
\hline Stipagrostis uniplumis & $18.3 b$ & 43.90 & 16.56 & 1.71 & 5.95 & 2.00 & 70.13 & 2.28 \\
\hline Schmidtia pappophoroides & $6.66 n$ & 71.83 & 20.25 & 2.21 & 9.95 & 2.91 & 107.2 & 2.57 \\
\hline Stipagrostis obtuse & 6.630 & 48.22 & 17.94 & 1.55 & 5.13 & 1.70 & 74.54 & 2.79 \\
\hline Stipagrostis ciliata & $9.39 \mathrm{j}$ & 41.50 & 14.86 & 1.82 & 5.57 & 2.17 & 65.92 & 3.22 \\
\hline Tricholaena monachne & $11.0 \mathrm{~g}$ & 52.18 & 20.31 & 1.60 & 6.97 & 1.90 & 82.96 & 2.58 \\
\hline s.e.m. & 0.0001 & & & & & & & \\
\hline$P$-value & $<0.0001$ & & & & & & & \\
\hline
\end{tabular}


Table 6. Percentage and volumes $\left(\mathrm{mL} \mathrm{g}^{-1} \mathrm{DM}\right)$ of methane production from the studied grasses Within columns, means followed by the same letter are not significantly different at $P=0.05$

\begin{tabular}{|c|c|c|c|c|c|c|c|c|}
\hline \multirow[t]{2}{*}{ Species } & \multicolumn{2}{|c|}{$2 \mathrm{~h}$} & \multicolumn{2}{|c|}{$12 \mathrm{~h}$} & \multicolumn{2}{|c|}{$24 \mathrm{~h}$} & \multicolumn{2}{|c|}{$48 \mathrm{~h}$} \\
\hline & $\%$ & $\mathrm{~mL}$ & $\%$ & $\mathrm{~mL}$ & $\%$ & $\mathrm{~mL}$ & $\%$ & $\mathrm{~mL}$ \\
\hline Anthephora argentea & $2.52 \mathrm{cde}$ & $0.81 \mathrm{ab}$ & $7.15 b$ & $5.51 \mathrm{a}$ & $9.02 \mathrm{a}$ & $12.7 \mathrm{a}$ & $8.59 \mathrm{e}$ & $22.7 b$ \\
\hline Aristida vestita & $2.86 \mathrm{ab}$ & $0.79 \mathrm{ab}$ & $4.59 \mathrm{i}$ & $3.15 \mathrm{i}$ & $5.62 \mathrm{~h}$ & $4.95 \mathrm{k}$ & $6.02 \mathrm{~g}$ & $8.45 \mathrm{~h}$ \\
\hline Brachiaria ciliaris & $2.48 \mathrm{cde}$ & $0.63 \mathrm{bcd}$ & $5.88 \mathrm{~g}$ & $3.58 \mathrm{fg}$ & $6.26 \mathrm{~g}$ & $5.65 \mathrm{j}$ & $8.52 \mathrm{e}$ & $12.1 \mathrm{~g}$ \\
\hline Cenchrus ciliaris & $2.26 \mathrm{efg}$ & $0.18 \mathrm{efg}$ & $6.54 \mathrm{~d}$ & $2.83 \mathrm{j}$ & $7.95 \mathrm{cde}$ & 4.381 & $8.16 \mathrm{e}$ & $7.68 \mathrm{i}$ \\
\hline Centropodia glauca & $2.34 \mathrm{def}$ & $0.37 \mathrm{def}$ & $6.51 \mathrm{~d}$ & $3.50 \mathrm{gh}$ & $7.63 \mathrm{de}$ & $6.14 \mathrm{i}$ & $9.46 \mathrm{~d}$ & $14.4 \mathrm{e}$ \\
\hline Cynodon dactylon & $2.146 \mathrm{fg}$ & $0.16 \mathrm{fg}$ & $5.33 \mathrm{~h}$ & $3.22 \mathrm{i}$ & $4.60 \mathrm{i}$ & 4.501 & $5.16 \mathrm{~h}$ & $7.10 \mathrm{i}$ \\
\hline Digitaria eriantha & $1.03 \mathrm{~g}$ & $0.05 \mathrm{~g}$ & $6.36 \mathrm{de}$ & $3.66 \mathrm{f}$ & $7.47 \mathrm{e}$ & $6.53 \mathrm{~h}$ & $9.85 \mathrm{~d}$ & $11.77 \mathrm{~g}$ \\
\hline Eragrostis trichophora & $2.578 \mathrm{dc}$ & $0.56 \mathrm{bcd}$ & $6.44 \mathrm{~d}$ & $4.31 \mathrm{~d}$ & $7.55 \mathrm{e}$ & $9.85 \mathrm{c}$ & $10.67 \mathrm{c}$ & $21.9 \mathrm{bc}$ \\
\hline Panicum coloratum & $2.33 \mathrm{def}$ & $0.21 \mathrm{efg}$ & $6.03 \mathrm{fg}$ & $3.17 \mathrm{i}$ & $8.91 \mathrm{a}$ & $7.28 \mathrm{~g}$ & $8.09 \mathrm{e}$ & $14.3 \mathrm{e}$ \\
\hline Pogonarthria squarrosa & $2.51 \mathrm{cde}$ & $0.67 \mathrm{bc}$ & $7.96 \mathrm{a}$ & $4.91 b$ & $8.34 \mathrm{bc}$ & $9.11 \mathrm{~d}$ & $11.77 \mathrm{a}$ & $22.0 \mathrm{~b}$ \\
\hline Setaria verticillata & $2.39 \mathrm{cdef}$ & $0.19 \mathrm{efg}$ & $5.35 \mathrm{~h}$ & $2.89 \mathrm{j}$ & $5.46 \mathrm{~h}$ & $4.02 \mathrm{~m}$ & $6.41 \mathrm{~g}$ & $6.37 \mathrm{j}$ \\
\hline Stipagrostis uniplumis & $2.01 \mathrm{~g}$ & $0.01 \mathrm{~g}$ & $6.20 \mathrm{de}$ & $4.18 \mathrm{e}$ & $6.90 \mathrm{f}$ & $7.61 \mathrm{f}$ & $7.37 \mathrm{f}$ & $13.3 \mathrm{f}$ \\
\hline Stipagrostis obtusa & $2.44 \mathrm{cdef}$ & $0.47 \mathrm{cde}$ & $6.53 \mathrm{~d}$ & $4.41 \mathrm{c}$ & $8.10 \mathrm{~cd}$ & $9.68 \mathrm{c}$ & $8.33 \mathrm{e}$ & $19.1 \mathrm{~d}$ \\
\hline Schmidtia pappophoroides & $2.53 \mathrm{cde}$ & $0.46 \mathrm{cde}$ & $7.20 \mathrm{~b}$ & $4.10 \mathrm{e}$ & $8.71 \mathrm{ab}$ & $8.08 \mathrm{e}$ & $11.06 \mathrm{a}$ & $19.7 \mathrm{~d}$ \\
\hline Stipagrostis ciliata & $3.10 \mathrm{a}$ & $1.01 \mathrm{a}$ & $6.84 \mathrm{c}$ & $4.86 \mathrm{~b}$ & $9.18 \mathrm{a}$ & $11.70 \mathrm{~b}$ & $11.33 \mathrm{ab}$ & $23.1 \mathrm{a}$ \\
\hline Tricholaena monachne & $2.69 \mathrm{bc}$ & $0.68 \mathrm{bc}$ & $5.89 \mathrm{~g}$ & $3.42 \mathrm{~h}$ & $6.81 \mathrm{f}$ & $6.05 \mathrm{i}$ & $9.69 \mathrm{~d}$ & $13.7 \mathrm{ef}$ \\
\hline s.e.m. & 0.093 & 0.009 & 0.078 & 0.032 & 0.161 & 0.103 & 0.190 & 0.250 \\
\hline$P$-value & $<0.0001$ & $<0.0001$ & $<0.0001$ & $<0.0001$ & $<0.0001$ & $<0.0001$ & $<0.0001$ & $<0.0001$ \\
\hline
\end{tabular}

Table 7. In vitro organic matter digestibility (IVOMD), metabolisable energy (ME), methane $\left(\mathrm{CH}_{4}\right)$ production, and per cent of energy lost as methane from the studied grasses after $24 \mathrm{~h}$ of incubation

Within columns, means followed by the same letter are not significantly different at $P=0.05$

\begin{tabular}{|c|c|c|c|c|c|}
\hline Scientific name & $\begin{array}{c}\text { IVOMD } \\
\left(\mathrm{g} \mathrm{kg}^{-1} \mathrm{DM}\right)\end{array}$ & $\begin{array}{c}\mathrm{ME} \\
\left(\mathrm{MJ} \mathrm{kg}^{-1} \mathrm{DM}\right)\end{array}$ & $\left(\mathrm{g} \mathrm{kg}^{-1} \mathrm{DM}\right)$ & ( $\mathrm{g} \mathrm{kg}^{-1}$ IVOMD) & $\begin{array}{c}\text { Lost energy as } \\
\mathrm{CH}_{4}(\% \mathrm{ME})\end{array}$ \\
\hline Anthephora argentea & $572.9 \mathrm{e}$ & $11.7 \mathrm{~b}$ & $12.7 \mathrm{a}$ & $15.6 \mathrm{a}$ & $2.24 \mathrm{a}$ \\
\hline Aristida vestita & $548.8 \mathrm{~g}$ & $9.56 \mathrm{~g}$ & $4.95 \mathrm{k}$ & $7.73 \mathrm{e}$ & $1.65 \mathrm{fg}$ \\
\hline Brachiaria ciliaris & $484.6 \mathrm{j}$ & $10.4 \mathrm{f}$ & $5.65 \mathrm{j}$ & $9.12 \mathrm{~d}$ & $1.92 \mathrm{def}$ \\
\hline Cenchrus ciliaris & 427.11 & $9.40 \mathrm{~h}$ & 4.381 & $6.33 \mathrm{f}$ & $1.72 \mathrm{gh}$ \\
\hline Centropodia glauca & $511.8 \mathrm{~h}$ & $7.59 \mathrm{k}$ & $6.14 \mathrm{i}$ & $9.11 \mathrm{~d}$ & $1.82 \mathrm{def}$ \\
\hline Cynodon dactylon & $610.1 \mathrm{a}$ & $12.3 \mathrm{a}$ & 4.501 & $7.39 \mathrm{e}$ & $1.20 \mathrm{~h}$ \\
\hline Digitaria eriantha & $420.7 \mathrm{~m}$ & $8.58 \mathrm{i}$ & $6.53 \mathrm{~h}$ & $10.30 \mathrm{c}$ & $1.98 \mathrm{bcdef}$ \\
\hline Eragrostis trichophora & $557.9 \mathrm{f}$ & $11.4 \mathrm{c}$ & $9.85 \mathrm{c}$ & $12.7 \mathrm{~b}$ & $1.16 \mathrm{~h}$ \\
\hline Panicum coloratum & $447.01 \mathrm{k}$ & $8.16 \mathrm{j}$ & $7.28 \mathrm{~g}$ & $10.56 \mathrm{c}$ & $2.18 \mathrm{abc}$ \\
\hline Pogonarthria squarrosa & $582.3 \mathrm{c}$ & $11.6 \mathrm{~b}$ & $9.11 \mathrm{~d}$ & $12.12 b$ & $2.12 \mathrm{abcd}$ \\
\hline Schmidtia pappophoroides & $407.90 \mathrm{o}$ & $6.12 \mathrm{~m}$ & $4.02 \mathrm{~m}$ & $10.60 \mathrm{c}$ & $1.86 \mathrm{cdef}$ \\
\hline Setaria verticillata & $577.7 \mathrm{~d}$ & $11.2 \mathrm{~d}$ & $7.61 \mathrm{f}$ & $6.55 f$ & $0.67 \mathrm{i}$ \\
\hline Stipagrostis ciliata & $406.9 n$ & $8.15 \mathrm{j}$ & $9.68 \mathrm{c}$ & $14.9 \mathrm{a}$ & $2.21 \mathrm{ab}$ \\
\hline Stipagrostis uniplumis & $446.9 \mathrm{k}$ & 6.701 & $8.08 \mathrm{e}$ & $10.32 \mathrm{c}$ & $1.91 \mathrm{def}$ \\
\hline Stipagrostis obtusa & $500.3 \mathrm{i}$ & $10.7 \mathrm{e}$ & $11.70 \mathrm{~b}$ & $12.01 \mathrm{~b}$ & $1.72 \mathrm{ef}$ \\
\hline Tricholaena monachne & $604.7 \mathrm{~b}$ & $12.2 \mathrm{a}$ & $6.05 \mathrm{i}$ & $9.88 \mathrm{c}$ & $1.31 \mathrm{gh}$ \\
\hline s.e.m. & 0.004 & 0.06 & 0.103 & 0.144 & 0.032 \\
\hline$P$-value & $<0.0001$ & $<0.0001$ & 0.001 & 0.001 & 0.001 \\
\hline
\end{tabular}

uncanopied areas in this arid region. Moreover, in such arid rangeland, trees provide better protection of herbaceous groundcover. In addition, the greater plant cover under canopied areas has a positive effect on fertility and water balance of soil, further creating a better microclimate for palatable perennial species with a high water-use efficiency, OM decomposition and nutrient dynamics (Abule et al. 2005; Snyman 2005). This better performance in plant cover and DM yield from arid grassland has been reported by other researchers in tropical and subtropical conditions (Abule et al. 2005; Snyman 2005; Abdallah et al. 2008).

\section{Chemical composition and gas production}

The nutrient compositions of studied species were comparable with the values reported for South African feeds and forages by Bredon et al. (1987) in a similar season. However, the CP values of most species were low in terms of animal nutritional needs. The cell-wall content (NDF, ADF and ADL) values were high for the studied grasses. The low CP and the high cell-wall contents observed in this study are due to seasonal fluctuation of nutrients, which is partly caused by seasonal dynamics of the plant nutrients. Compared with the wet season, when $\mathrm{N}$ is translocated to actively photosynthesising tissues, resulting in a lower carbohydrate: $\mathrm{N}$ ratio, in the dry season nutrients 
Table 8. Pearson correlation between in vitro methane $\left(\mathrm{CH}_{4}\right)$ production and chemical constituents of studied grasses NDIN, ADIN: Neutral and acid detergent insoluble nitrogen; IVOMD, in vitro organic matter digestibility. ${ }^{*} P<0.05$

\begin{tabular}{|c|c|c|c|c|c|c|c|c|c|}
\hline $\begin{array}{l}\text { Major feed } \\
\text { components }\end{array}$ & $\mathrm{CH}_{4}$ & Fibre components & $\mathrm{CH}_{4}$ & $\begin{array}{l}\text { Nitrogen } \\
\text { component }\end{array}$ & $\mathrm{CH}_{4}$ & $\begin{array}{l}\text { Fermentation } \\
\text { characteristics }\end{array}$ & $\mathrm{CH}_{4}$ & $\begin{array}{l}\text { Volatile } \\
\text { fatty acid }\end{array}$ & $\mathrm{CH}_{4}$ \\
\hline Dry matter & 0.206 & Neutral detergent fibre & $0.652 *$ & Crude protein & $-0.357 *$ & Gas production $24 \mathrm{~h}$ & -0.13 & Total VFA & 0.251 \\
\hline Ash & $-0.602 *$ & Acid detergent fibre & $0.703 *$ & NDIN & $-0.308^{*}$ & Gas production $48 \mathrm{~h}$ & -0.20 & Acetate (A) & $0.307 *$ \\
\hline \multirow[t]{3}{*}{ Ether extract } & $-0.299 *$ & Non-fibre carbohydrate & $-0.635^{*}$ & & & IVOMD & 0.03 & Isobutyrate & $0.413 *$ \\
\hline & & Cellulose & $0.658 *$ & & & & & Butyrate & $0.323 *$ \\
\hline & & & & & & & & Valeric & 0.16 \\
\hline
\end{tabular}

Table 9. Linear regression equation to predict $\mathrm{CH}_{4}$ (g/KG DM) from chemical constitutes ME, and IVOMD of the grasses studies

EE, Ether extract; NDF and ADF, neutral and acid detergent fibre; NDIN and ADIN, neutral and acid detergent insoluble nitrogen; ADL, acid detergent lignin; CP, crude protein; NFC, non-fibre carbohydrate

\begin{tabular}{lcr}
\hline Equation & $R^{2}$ & \multicolumn{1}{c}{$P$} \\
\hline $\mathrm{CH}_{4}=8.05-0.048 \mathrm{Ash}$ & 0.35 & $<0.001$ \\
$\mathrm{CH}_{4}=7.95-0.1822 \mathrm{EE}$ & 0.07 & 0.039 \\
$\mathrm{CH}_{4}=8.07-00171 \mathrm{EE}-0.0475 \mathrm{Ash}$ & 0.33 & $<0.001$ \\
$\mathrm{CH}_{4}=-22.7+0.035 \mathrm{NDF}+0.0653 \mathrm{NDIN}$ & 0.49 & $<0.001$ \\
$\mathrm{CH}_{4}=-7.95+0.008 \mathrm{NDF}+0.0286 \mathrm{ADF}+0.08 \mathrm{ADL}$ & 0.46 & $<0.001$ \\
$\mathrm{CH}_{4}=-6.19+0.00264 \mathrm{ADF}-0.213 \mathrm{ADIN}$ & 0.51 & $<0.001$ \\
$\mathrm{CH}_{4}=-12.1+0.0232 \mathrm{NDF}$ & 0.41 & $<0.001$ \\
$\mathrm{CH}_{4}=-8.08+0.0289 \mathrm{ADF}$ & 0.48 & $<0.001$ \\
$\mathrm{CH}_{4}=1.72+0.0453 \mathrm{ADL}$ & 0.11 & 0.009 \\
$\mathrm{CH}_{4}=3.99-0.0259 \mathrm{CP}$ & 0.10 & 0.013 \\
$\mathrm{CH}_{4}=5.98-0.01 \mathrm{CP}-0.281 \mathrm{ADIN}-0.0304 \mathrm{NDIN}$ & 0.22 & 0.003 \\
$\mathrm{CH}_{4}=7.30-0.356 \mathrm{ADIN}-0.0304 \mathrm{NDIN}$ & 0.16 & 0.007 \\
$\mathrm{CH}_{4}=8.72-0.0233 \mathrm{NFC}$ & 0.39 & $<0.001$ \\
\hline
\end{tabular}

accumulate as lignin, cutin, and other phenolic plant defensive substances in the cell wall (Van Soest 1994), and this influences the nutritive quality of forage. This generally results in low fermentation and OMD and consequently results in higher methane emissions. Supplementation with concentrate is important to improve digestibility and enhance propionate production. Small-scale farmers of tropical and subtropical Africa can supplement ruminants with foliage from trees and shrubs, because they remain fairly constant during the early dry period and contain a reasonable amount of $\mathrm{CP}(\geq 14 \%)$, needed by ruminants for a medium level of production (Subba 1999).

The differences in the volume of gas produced among grass species and duration of times is mainly due to differences in the fermentable $\mathrm{OM}$ and fibre contents. This in turn affects the rate and extent of substrate fermentation to short-chain fatty acids, carbon dioxide and methane (Blümmel and Becker 1997). The amount of short-chain fatty acids produced is related to OMD and energy content of feed. However, methane production is an energetic loss, as the portion of animal feed converted to methane and lost through eructation (Getachew et al. 2005).

\section{Production of methane and other fermentation end products}

In ruminants, methane is produced by rumen microbes through anaerobic fermentation of cell contents and cell-wall contents of feed. The variation in methane production among grass species in the present study may be attributed to their significant differences in chemical constituents such as CP, ash, ether extract, ADF, NDF, ADL, NDIN, ADIN and NFC concentration. Similarly, the difference in methane production across incubation times was attributed to the difference in the rate of fermentation of these feeds. Higher methane production for Anthephora argentea and Aristida vestita grasses for most of the incubation times was due to their high cell-wall content (ADF, NDF, ADL, cellulose and hemicellulose), NFC content, IVOMD, ME and fermentation potential. In addition, the efficiency expressed as the ratio of methane to total gas produced was also comparatively higher for these grasses. On the other hand, Cenchrus ciliaris and Panicum coloratum produced the lowest amount of methane during 12, 24 and $48 \mathrm{~h}$, and this might be due to the low level of cell-wall contents (ADF, NDF, ADL, cellulose and hemicellulose) and the acetate : propionate ratio. There is little information on methane production for tropical perennial grasses under tropical conditions, with which to compare our data. We assume that the higher values in our report than for temperate conditions (Getachew et al. 2005) might be attributed to relatively higher levels of fibre and lignin (Van Soest 1994) recorded for dry season harvested grasses (Table 1) and associated low values of digestibility, and due to the lower digestibility (13\%) of most tropical grasses compared with temperate grasses (Minson 1990).

Similar to our report, there are many findings showing that methane production could be influenced by the contents and nature of cell wall digested (NDF, ADF, ADL, cellulose, and hemicelluloses) (Santoso et al. 2003, 2007; Singh et al. 2012). This is because the OM digestion, fermentation and production of short-chain VFAs of forages are mainly dependent on their structural factors and the relative proportion of cell types present in their tissues, and the existence of factors restricting microbial access to walls (Van Soest 1994). On the other hand, increasing protein in the diet is expected to decrease methane emission because of direct negative association of protein with methane (Table 7) or the replacement in the diet of methanogenic carbohydrate with protein (Pelchen and Peters 1998).

\section{Association between methane, IVOMD, VFA and chemical composition}

In the present study, a significant association was revealed between methane production and various studied parameters. Similarly, many researchers have explained the relationship between the quality of feed expressed in terms of chemical constituents and digestibility, and methane production (Santoso 
et al. 2003, 2007; S i $\mathrm{n} \mathrm{g} \mathrm{h}$ et al. 2012). This is mainly because fermentability of feed to its end products is primarily determined by digestibility, which mainly depends on its composition. For example, VFA concentration and its relative proportions, which mainly influence methane production, are influenced by the nature and fermentation of carbohydrate (Johnson and Johnson 1995).

The positive correlation between methane production and cellwall contents (NDF, ADF, cellulose and lignin) observed in this study is in agreement with previous reports (Moss 2000; Singh et al. 2012). The negative correlation between $\mathrm{CP}$ and methane production is in agreement with the finding of Moss (2000). Moreover, negative correlations of methane production with energy and ether extract are in agreement with previous finding by Yan et al. (2009) and Ellis et al. (2008), respectively.

Our prediction equations for enteric methane production with $\mathrm{ADF}$ and NDF had $R^{2}$ values $0.48(P<0.01)$ and $0.41(P<$ $0.01)$, whereas equations using protein fractions and carbohydrate fractions had $R^{2}$ values $0.51(P<0.03)$ and $0.49(P$ $<0.01)$, respectively. This shows that carbohydrate and its fractions give a better estimate of in vitro methane production from dry-season tropical perennial grasses. This finding is in agreement with previous finding of Johnson and Johnson (1995), who identified that carbohydrate fed to livestock has a major effect on methane production, most likely because of the effect on rumen $\mathrm{pH}$ and its microbial population. Similar to this finding, Santoso et al. ( 2007) and Singh et al. ( 2012) indicated that carbohydrate fractions (NDF and ADF) are better methane predictors than feed components.

\section{Conclusion}

The results of the present study showed that methane production varied between grass species, which shows room for screening species for lower methane production. The negative correlation between methane production and $\mathrm{CP}$ indicates that screening and selecting perennial grass forages for higher $\mathrm{CP}$ content will help to mitigate methane production in tropical grassland. The fact that most palatable perennial grasses produced low to medium methane might also indicate that good-quality grasses are good for methane mitigation. Moreover, in formulating a ration for ruminant animals, the use of grass with lower methane production might have potential to mitigate methane emission from agriculture.

\section{Acknowledgements}

The research leading to these results has received funding from the European Community's Framework Program (FP7/2007-2013) under the grant agreement no. 266018ANIMALCHANGE. The authors are grateful for the co-funding of the research by the Department of Science and Technology, South Africa. The authors are also grateful for a University of Pretoria bursary award. The methane analysis system in our department was established by continuous effort of the team; Mr Christo Jacobs has played a great role and deserves our heartfelt thanks.

\section{References}

Abdallah F, Noumi Z, Touzard B, Belgacem AO, Neffati M, Chaieb M (2008) The influence of Acacia tortilis (Forssk.) subsp. raddiana (Savi) and livestock grazing on grass species composition, yield and soil nutrients in arid environments of South Tunisia. Flora 203, 116-125. doi:10.1016/ j.flora.2007.02.002
Abule E, Snyman HA, Smit GN (2005) The influence of woody plants and livestock grazing on grass species composition, yield and soil nutrients in the Middle Awash Valley of Ethiopia. Journal of Arid Environments $\mathbf{6 0}$, 343-358. doi:10.1016/j.jaridenv.2004.04.006

AOAC (2002) 'Official methods of analysis.' (Association of Official Analytical Chemists: Arlington, VA, USA)

Arthington JD, Brown WF (2005) Estimation of feeding value of four tropical forage species at two stages of maturity. Journal of Animal Science 83, $1726-1731$.

Beauchemin KA, McAllister TA, McGinn SM (2009) 'Dietary mitigation of enteric methane from cattle.' CAB Reviews: Perspectives in Agriculture, Veterinary Science, Nutrition and Natural Resources. pp. 4-18. (CABI: Wallingford, UK)

Blümmel M, Becker K (1997) The degradability characteristics of fifty-four roughages and roughage neutral detergent fibre as described by in vitro gas production and their relationship to voluntary feed intake. The British Journal of Nutrition 77, 757-768. doi:10.1079/BJN19970073

Bredon RM, Stewart PG, Dugmore TJ (1987) 'A manual on the nutritive value and chemical composition of commonly used South African farm feeds.' (Natal Region, Department of Agricultural and Water Affairs, South Africa: Pretoria, South Africa)

Chaves AV, Thompson LC, Iwaasa AD, Scott SL, Olson ME, Benchaar C, Veira DM, McAllister TA (2006) Effect of pasture type (alfalfa vs. grass) on methane and carbon dioxide production by yearling beef heifers. Canadian Journal of Animal Science 86, 409-418. doi:10.4141/A05-081

Daget P, Poissonet J (1971) An ecological analysis method of prairies. Criteria of application. Ann. Agronomy 22, 5-41.

Ellis JL, Dijkstra J, Kebreab E, Bannink A, Odongo NE, McBride BW, France J (2008) Aspects of rumen microbiology central to mechanistic modeling of methane production in cattle. The Journal of Agricultural Science 146, 213-233. doi:10.1017/S0021859608007752

Engels EAN, Van der Merwe FJ (1967) Application of an in vitro technique to South African forages with special reference to the effect to certain factors on the results. South African Journal of Agricultural Science 10, 983-992.

Getachew G, DePeters EJ, Robinson PH, Fadel JG (2005) Use of an in vitro rumen gas production technique to evaluate microbial fermentation of ruminant feeds and its impact on fermentation products. Animal Feed Science and Technology 123-124, 547-559. doi:10.1016/j.anifeedsci. 2005.04.034

Goering HK, Van Soest PJ (1970) 'Forage fiber analyses, apparatus, reagents, procedures, and some applications.' USDA Agricultural Handbook No. 379. pp. 1-20. (USDA: Washington, DC)

Grant RJ, Mertens DR (1992) Impact of in vitro fermentation techniques upon kinetics of fiber digestion. Journal of Dairy Science 75, 1263-1272. doi:10.3168/jds.S0022-0302(92)77876-X

Hindrichsen IK, Kreuzer M, Machmuller A, Bach Knudsen KE, Madsen J, Wettstein HR (2003) Methane release and energy expenditure of dairy cows fed concentrates characterized by different carbohydrates. In 'Proceedings of the EAAP-Symposium on Energy and Protein Metabolism and Nutrition'. (Eds WM Souffrant, CC Metges) pp. 413-416. (Academic Publisher: Wageningen, The Netherlands)

Johnson KA, Johnson DE (1995) Methane emission from cattle. Journal of Animal Science 73, 2483-2492.

Le Houe'rou HN (1987) Aspects Meteorologiques de la Croissance et du Developpement Vegetal Dans les Deserts et Les Zones Menacees de Desertification. PNUE, Nairobi et OMM, Genève.

Le Roux LG (2013) Physiochemical controls on the formation and stability of atacamite in the soil surrounding the Spektakel mine, Northern Cape Province, South Africa. MSc Thesis, Stellenbosch University, Free State, South Africa.

Leng RA (2008) The potential of feeding nitrate to reduce enteric methane production in ruminants. A Report to the Department of Climate Change Commonwealth Government of Australia, Canberra, ACT, Australia. Available at: www.penambulbooks.com 
Lovett D, Lovel LS, Stack L, Callan J, Finlay M, Conolly J, O’Mara FP (2003) Effect of forage concentrate ratio and dietary coconut oil level on methane output and performance of finishing beef heifers. Livestock Production Science 84, 135-146. doi:10.1016/j.livprodsci.2003.09.010

Mc Geough EJ, O’ki ELYP, Hart KJ, Moloney AP, Boland TM, Kenny DA (2010) Methane emissions, feed intake, performance, digestibility, and rumen fermentation of finishing beef cattle offered whole-crop wheat silages differing in grain content. Journal of Animal Science 88, 2703-2716. doi:10.2527/jas.2009-2750

McAllister TA, Okine EK, Mathison GW, Cheng KJ (1996) Dietary, environmental and microbiological aspects of methane production in ruminants. Canadian Journal of Animal Science 76, 231-243. doi:10.4141/cjas96-035

McDonald P, Stirling AC, Henderson AR, Dewar WA, Stark GH, Davie WG, Macpherson HT, Reid AM, Salter J (1960) Studies on ensilage. Technical Bulletin No. 24. pp. 1-83. Edinburgh School of Agriculture, Edinburgh, Scotland.

McDonald P, Edwards R, Greenhalgh JFD, Morgan CA, Sinclair LA, Wilkison RG (2011) 'Animal nutrition.' 7th edn (Harlow, Pearson Education, Prentice Hall: London)

Menke KH, Steingass H (1988) Estimation of the energetic feed value obtained from chemical analysis and in vitro gas production using rumen fluid. Animal Research and Development 28, 7-55.

Minson DJ (1990) 'Forages in ruminant nutrition.' (Academic Press: San Diego, CA, USA)

Moss AR (2000) Methane production by ruminants: Its contribution to global warming. Annales de Zootechnie 49, 231-253. doi:10.1051/animres: 2000119

Mould FL, Morgan R, Kliem KE, Krystallidou E (2005) A review and simplification of the in vitro incubation medium. Animal Feed Science and Technology 123-124, 155-172. doi:10.1016/j.anifeedsci.2005. 05.002

Ørskov ER, Mcdonald I (1979) The estimation of protein degradability in the rumen from incubation measurements weighted according to rate of passage. The Journal of Agricultural Science 92, 499-503. doi:10.1017/ S0021859600063048

Ottenstein DM, Bartley DA (1971) Separation of free acids C2-C5 in diluted aqueous solution column technology. Journal of Chromatographic Science 9, 673-681. doi:10.1093/chromsci/9.11.673

Pelchen A, Peters KJ (1998) Methane emissions from sheep. Small Ruminant Research 27, 137-150. doi:10.1016/S0921-4488(97)00031-X

Rooyen NV (2001) 'Flowering plants of the Kalahari dunes.' (Natal Region, Department of Agricultural and Water Affairs, South Africa: Pretoria, South Africa)

Santoso B, Kume S, Nonaka K, Kimura K, Mizokoshi H, Gamo Y, Takahashi $\mathrm{J}$ (2003) Methane emission, nutrient digestibility, energy metabolism and blood metabolites in dairy cows fed silages with and without galacto- oligosaccharides supplementation. Asian-Australasian Journal of Animal Sciences 16, 534-540.

Santoso B, Mwenya B, Sar C, Takahashi J (2007) Methane production and energy partition in sheep fed timothy hay silage- or hay-based diets. Journal of Animal Science and Veterinary (JITV) 12, 27-33.

SAS (2002) 'SAS version 9.0.' (SAS Institute Inc.: Cary, NC, USA)

Singh S, Kushwaha BP, Naga SK, Mishra AK, Singh A, Anele UY (2012) In vitro ruminal fermentation, protein and carbohydrate fractionation, methane production and prediction of twelve commonly used Indian green forages. Animal Feed Science and Technology 178, 2-11. doi:10.1016/j.anifeedsci.2012.08.019

Sniffen CJ, O'Connor JD, Van Soest PJ, Fox DG, Russell JB (1992) A net carbohydrate and protein system for evaluating cattle diets. II. Carbohydrate and protein availability. Journal of Animal Science 70, 3562-3577.

Snyman HA (2005) Rangeland degradation in a semi-arid South Africa-I: influence on seasonal root distribution, root/shoot ratios and water-use efficiency. Journal of Arid Environments 60, 457-481. doi:10.1016/ j.jaridenv.2004.06.006

Subba DB (1999) Tree fodders and browses plants as potential nutrient suppliers for ruminants. In 'Proceedings of the 3rd National Workshop on Livestock and Fisheries Research'. (Eds SP Neopane, RC Khanal) pp. 97-109. (Nepal Agricultural Research Council: Kathmandu, Nepal)

Tavendale MH, Meagher LP, Pacheco D, Walker N, Attwood GT, Sivakumaran S (2005) Methane production from in vitro rumen incubations with Lotus pedunculatus and Medicago sativa, and effects of extractable condensed tannin fractions on methanogenesis. Animal Feed Science and Technology 123-124, 403-419. doi:10.1016/ j.anifeedsci.2005.04.037

Theodorou MK, Williams BA, Dhanoa MS, McAllen AB, France J (1994) A simple gas production method using pressure transducers to determine the fermentation kinetics of ruminant feed. Animal Feed Science and Technology 48, 185-197. doi:10.1016/0377-8401(94)90171-6

Tilley JMA, Terry RA (1963) A two-stage technique for the in vitro digestion of forage crops. Journal of the British Grassland Society 18, 104-111. doi:10.1111/j.1365-2494.1963.tb00335.x

Van Soest PJ (1994) 'Nutritional ecology of the ruminant.' 2nd edn (Comstock Publishing Associates/Cornell University Press: Ithaca, NY, USA)

Van Soest PJ, Robertson PJ, Lewis BA (1991) Methods for dietary fiber, neutral detergent fiber, and non starch polysaccarides in relation to animal nutrition. Journal of Dairy Science 74, 3583-3597. doi:10.3168/jds.S0022-0302(91)78551-2

Yan T, Porter MG, Mayne CS (2009) Prediction of methane emission from beef cattle using data measured in indirect open circuit respiration calorimeters. Animal 3, 1455-1462. doi:10.1017/S175173110900473X 